eene werkschool heeten. En uit deze opmerking nemen wij aanleiding om den wensch te uiten, dat an de practische vorming eenig industriëel onderwijs mogt verbonden worden. Gedurende de wintermanden toch zouden de leerlingen eenige avonduren nuttig kunnen bezig gehouden worden met lessen in de zoo even aangeduide vakken. Lokalen, hulpmiddelen en onderwijzers zouden in de gemeente Vlissingen zonder moeite kunnen gevonden worden, en de kosten zouden niet hoog loopen. - Mogt eene herhalingschool voor de vakken vau lager onderwijs daaraan kumen voorafgaan, zoo zoude aan eene werkelijk bestande behoefte tevens voldaan worden.

V.

\title{
EENE VINGERWIJZING UIT DEN VREEMDE!
}

\section{(Ingezonden.)}

Het volgende vinde hier eene plats als een nieuw bewijs voor de warheid, dat gezondheid en levensd nur voor een goed deel afhankelijk zijn van hygiënische maatregelen. Die bewijzen kunnen niet te zeer worden rermenigvuldigd. Want eerst wanneer de kennis dier waarheid zal zijn doordrongen in alle standen der mantschappij, wanneer de overtuiging die thans nog slechts het deel is van weinigen, de overtuiging des volks zal zijn geworden, is in dit opzigt voor Nederland iets goeds te verwuehten!

Sedert verscheidene jaren heeft men in Stuttgart veel gedaan voor de openbare gezondheidsregeling. De goede vruchten daarvan hebben zich niet lang laten wachten, zoo als uit het onderstaande blijkt:

De bevolking van Stuttgart bedroeg in 184943,742 , in 185245,814 en in 185546,507 inwoners. De bevolking is derhalve steeds toegenomen.

De sterfte heeft bedragen: in 18521062 , in 18531058 , in 1854 1046 en in 1855985 personen. Het antal sterfgevallen is derhalve steeds verminderd, niettegenstande de bevolking vermeerderde.

De sterfte verhouding was, na aftrek der doodgeborenen:

$$
\begin{array}{r|r|r|r|}
1847-1850=1: 44 . & 1852:=1: 45 . & 1854=1: 46 \\
1851=1: 46 . & 1853=1: 46 . & 1855=1: 49,9
\end{array}
$$

In vroegere jaren (vóórdat er zorg werd besteed aan de openbare gezondheidsregeling) was de sterfte veel grooter. Van $1822-1832 \mathrm{~b} . \mathbf{v}$. was zij $=1: 37$.

Hoe lang zal het nog duren eer men ook omtrent Nederland zulke gunstige gevolgen eener hygiënische hervorming zal kumnen mededeelen? 